\title{
Illuminating the Darker Side of Ageing A Special Issue of the Journal of Population Ageing
}

\author{
Ashley John Moyse ${ }^{1} \cdot$ Joshua Hordern ${ }^{2}$
}

Published online: 12 July 2021

(๑) The Author(s), under exclusive licence to Springer Nature B.V. 2021

Western nations often focus on policies and programming set toward healthy or successful ageing strategies and consumer-market opportunities for persons moving toward and living out their later life. Such thinking can also be found in the Global South too and other non-Western cultures and locations (Møller \& Ferreira, 1992; Fernández-Ballesteros et al., 2010; Cassim, 2015; Feng et al., 2015; Rabe, 2015). However, "successful ageing" is not without its critics. The experiences of some persons in later life where failure to achieve the successes of healthy ageing add fodder for further study and critical reflection. Moreover, that some persons grow tired of living in later life and despair of the depredations incurred by frailty and finitude also warrants further study. When suffering persists and existential gravity burdens persons in later life, there is particular need to unite the capacities of empirical research and measured outcomes with other forms of analysis in order to illuminate this darker side of ageing.

Accordingly, taking a different approach relative to the trend toward research outcomes and discussions concerning active, healthy, or successful ageing, The McDonald Centre for Theology, Ethics, and Public Life at the University of Oxford set toward thinking about and giving attention to the existential gravity of later life. Such gravity is often marked by the challenges introduced by corporeal depredations and psychological demands that ageing bodies might introduce. Corresponding to such depredations and demands, the writings of Austrian essayist Jean Améry (born Hanns Chaim Mayer, 1912-1978), ${ }^{1}$ specifically his Über das Altern: Revolte und

\footnotetext{
${ }^{1}$ For those unfamiliar with Améry, he was born in Vienna, Austria. He was a survivor of the Second World War, throughout which he endured torture and incarceration at the hands of the Nazi regime. After the war, he spent many years in Brussels while writing as a journalist. And in 1966, Améry published Jenseits von Schuld und Sühne. Bewältigungsversuche eines Überwältigten [later translated into English, At the Mind's Limits: Contemplations by a Survivor on Auschwitz and Its Realities]. This publication preceded two further publications of note. The first, Améry's On Aging (1968), which was developed

Ashley John Moyse

ashley.moyse@theology.ox.ac.uk

1 McDonald Centre for Theology, Ethics and Public Life, Faculty of Theology and Religion, University of Oxford, Oxford, UK

2 Harris Manchester College, Faculty of Theology and Religion, University of Oxford, Oxford, UK
} 
Resignation [On Aging: Revolt and Resignation] (1968), was introduced to set the conference précis, which contributing speakers were invited to consider.

Thus, the 2020 McDonald Centre Annual Conference, Ageing and Despair, gathered theologians and philosophers for a virtual conversation with medical and nursing professionals as well as health care strategists and ageing researchers such that the gravity of old age, including subjective experiences of suffering and despair, and the threats of death and dying, could be foregrounded. Such suffering and despair corresponds to the darker side of ageing, of which this special issue has taken interest. However, such suffering and despair, or the study of the experiences of older adults that excite such suffering and despairing, are often occluded by research that celebrates emancipatory ideals and offers strategies for promoting 'successful ageing'. Such ideals and strategies often focus on narratives of technological and economic agency, i.e., urgent action and market commodities that claim to reverse or delay the onset of frailties and experiences of ageing as an unwanted burden. Other such research illuminates extrinsic disadvantages that compound age-related distresses, giving attention to income inequalities, housing inadequacies, and service limitations that can be remediated by providers or provisions. Yet, as the conference organisers and guest editors of this issue have considered, little attention is given to the type of subjective affairs and experiences, i.e., the existential gravity, of ageing and the experiences of pain, suffering, and despair as outlined by Améry over fiftyyears ago.

Illuminating the darker side of ageing, the depiction of old age that Améry paints, is certainly not one successful ageing strategists and apologists will readily turn toward. It is a picture of ageing that some might introduce when discussing the Fourth age (Laslett, 1991). The Fourth age is considered as a problem of the "old" old (Neugarten, 1974), where pathology and fear persist. It is a category of old age that gerontologists, among others, describe as that period of older life marked by unwanted suffering; by experiences persons do not want to experience (Gilleard, 2007). This picture of "old" older life, or of the deleterious experiences incumbent to the Fourth age, is paralleled by Améry's reflections on aging that conjures an image of ageing where the costs that age brings to the human body, mind, and spirit are foregrounded.

But such an image is one that many do not want to contemplate, let alone to confront. In contrast to this trend and following from the September 2020 interdisciplinary event, this special issue weights the existential gravity of ageing by shining a light on ageing's darker side. 'Illuminating' in the issue's title, therefore, has a double meaning. In the first instance, to illuminate is to uncover the subjective experiences of later life that are difficult and remain as fodder for despair-bringing such experiences into the light. In the second instance, to illuminate the darker side of ageing is to offer a differently positive (or illuminated) narrative for later life that is accounts for the perturbations and depredations, the

Footnote 1 (continued)

from a series of radio lectures, and then Hand an sich Legen. Diskurs über den Freitod [On Suicide: A Discourse on Voluntary Death] (1976). He subsequently died by his own hand in 1978. 
fatigue and suffering in later life, while sustaining hope and joy amidst such circumstances. In both instances, researchers in the humanities, such as theologians, philosophers or ethicists, can play an important role, drawing on the distinctive resources of their disciplines, in concert with and sometimes contest with more empirical forms of analysis.

Fatigue or suffering focuses, in part, key emphases in the first three papers of this issue. The authors are united on this point of departure: that some persons experience suffering not only in but also because of later life demands a thinking again about the ways in which one might respond to such suffering.

Accordingly, Els van Wijngaarden (Universiteit voor Humanistiek [University of Humanistic Studies], NLD) opens the special issue with an examination that follows the question, "what are appropriate ways to face and respond to experiences of suffering in old age?" van Wijngaarden's "The darker side of ageing: Towards an ethics of suffering that emphasises the primacy of witnessing" introduces the concept of suffering while exploring particular features considered essential. The conceptual work anticipates the experiences of suffering. That is to suggest, "suffering from life in old age" as a concept is delimited further by the stories of persons experiencing the dark side of ageing. Themes pulled from such stories highlight a range of experiences where older persons felt disconnections from self-identity, bodily capacities, social relations, and from positive accounts of future life. Van Wijngaarden turns from these accounts to offer a call to develop an ethics of suffering that is able to attend to and to confront the manifestations of meaninglessness, sorrow, distress, and anguish persons growing tired of life might experience. Van Wijngaarden uses the imagery of giving witness to the darker sides of ageing that cannot be resolved, or made potentially meaningful, but must be named, storied, and shared. Her approach stands alongside and is distinct from other contemporary approaches to suffering, which might aim to make suffering meaningful, or to give an account of suffering as inevitable, demanding an attitude of acceptance or indifference, or to consider suffering as harm to be resolved or eliminated. The communicative witness that van Wijngaarden introduces as an ethics of suffering "implies careful and respectful listening and responding to the voice of those who suffer".

Like van Wijngaarden, Chris Gilleard's (University College London, UK) "Bearable and unbearable suffering in later life" is concerned with the nature of suffering. His interest is focused on those persons who, while suffering the depredations that can become familiar to those in later life, find the burden of physical pain, loss of control, and deteriorating quality of life intractable or unbearable. Both Gilleard and van Wijngaarden examine the nature of suffering and ways in which suffering might become recognised, or assessed in Gilleard's essay. Yet Gilleard pursues a subsequent question raised by an "enabling script" that narrates later life, or old age, as that which might rightly come to an end by way of one's own hand-by way of medical assistance in dying. Pain, suffering, and corresponding distress seem to give warrant for requests to solicit and to control the timing of one's death in response to the unbearableness of frail later life. The notion of having lived a fulfilling life, which needn't endure the threats of loss, pain, indignity, and helplessness, anchors Gilleard's initial reflection on the possibility of suicide (whether by one's own hand or mediated by medical professionals) in later life. And he concludes by examining, 
in part, reflections by theologian Paul Badham, who offers a consideration in support of assisted dying.

Rather than reflecting on the possibility of escaping suffering through medically assisted dying, Frits de Lange's (Protestentse Theologische Universiteit [Protestant Theological University], NLD/ Stellenbosch University, ZA) "Suffering from or in old age? The existential gravity of ageing" examines imaginaries that look to mediate ageing by solving the problem of dying. Not only in agreement with the phenomenological perspectives that ageing remains an existential affair, and therefore concomitant to the previous essay, de Lange labours to make a case that the experiences of persons in later life are existential in nature and cannot, simply, be resolved through technological interventions. Ageing and suffering are not mere technological problems to be resolved by medicine or machine. Extreme affliction with pains, distresses, and losses of various kinds (physical, social, etc.) are existentially personal and real. In concert with van Wijngaarden, de Lange is resolute: the experiences of ageing persons, especially those which are existentially weighty or burdensome, must be given attention so that persons in later life might be not only supported but also understood. Rather than following after a technological imperative that might "fix" our pains but never our "experiences of meaninglessness", de Lange calls for an ethics of caring.

Of course, de Lange's criticism of the reductionist technological representation of ageing as a pathology to be cured might not appeal to those who have been nurtured by the scholarship and ideals that extend from John W. Rowe and Robert Kahn. Rowe and Kahn's (1998) language of "successful ageing" has offered a grammatical foundation upon which much of contemporary gerontology stands. Its focus on health promotion, disease avoidance, physical and cognitive performance, and social well-being and productivity are corollaries of liberal or late modern values which prioritise the collation of choice options and individual, or self-determining, control throughout the life course. The belief of those committed to the successful ageing paradigm is that the frailty of old age, or becoming "old" old, can be deferred and, with the right kinds of interventions, reversed.

The dominance of the "successful ageing" grammar has shaped not only the language but also the conceptual apparatus that promises to make sense of the ways in which persons might negotiate ageing. But Michael Mawson (Charles Sturt University, AUS) points to a particular lacuna in Rowe and Kahn's work, which has been noted by scholars of religion. Labouring to find a place within the growing body of gerontological literature, and to fill in the gap in questions concerning spirituality and ageing, researchers have often accommodated empirical methods and quantifiable measures to study "spirituality" within what can be identified as the "immanent frame". But Mawson's "Should we pursue success and spirituality in ageing? Framing religious contributions to ageing research" laments that the immanentalisation of the study of spirituality and ageing tends to over-generalises its findings rather than study the particularity of practices, texts, and traditions of specific religious communities-particularities that might have something new, different or enabling to say to and for those persons ageing toward later life and death. Taking the meaning and experiences of suffering into consideration, where the dominant narratives of successful ageing might focus on strategies of avoidance or management, research in 
spirituality might show how "spiritual practices" can be considered as instrumental for success. But fitting spirituality into the immanent frame, as Mawson concludes, might occlude the more significant insights and practices that might challenge the guiding assumptions and normative practices of successful ageing.

Ashley John Moyse's (University of Oxford, UK) essay aims to answer Mawson's call. "Bearing the burdens we (don't tend to) bare: Independence as 'one more opportunity for me to fail" " critically assesses the prominence of independence and autonomy in successful or health ageing policy and practices. It goes further to suggest such thinking reveals anthropological assumptions (ideals about human being) that render ageing and older persons vulnerable to experiencing despair when confronting the limitations and losses incumbent to the Fourth age. The argument here, likely controversial for many, challenges particular icons of successful ageing, like independence, which Moyse marks as an illusory, and perhaps pernicious, ideal. As such, independence while celebrated as a characteristic of successful ageing also risks leaving persons vulnerable to experiences of despair when it is lost due to agerelated declines in physical and cognitive competencies. Drawing upon Dietrich Bonhoeffer's theological anthropology (understanding of human person and relations) and ethics, Moyse shows how vicarious representative action is an ethic that commits to attend to the particularities of another's corporeal human being. Such action conditions an attention to the reality of later life and the essential practices for living life responsibly with and for each other, both young and old alike. Such mutually dependent and responsible/responsive action is considered as necessary to human being and so that persons might be enabled not onto to bare (reveal) the burdens of later life but also to bear (carry) them, together.

Finally, Autumn Alcott Ridenour (Gordon-Conwell Theological Seminary, USA) concludes the issue with "'Elderhood' and sabbath rest as vocation: Identity, purpose, and belonging". With parallel concerns to those introduced in Moyse's essay, Ridenour recognises the challenges persons confront while ageing, which renders such persons vulnerable to despair. Specifically, Ridenour turns to theological anthropology and ethics, which are marked by communal belonging and dependent participation. Her attention to Augustinian anthropology in conversation with geriatrician Louise Aronson furnishes a rich interdisciplinary study of ageing across the life stages that remains critical of familiar Western and liberal ideals, including autonomy, self-determination, and productivity. That these aims remain as cultural priorities is curious since these commonly go frustrated and unfulfilled in later life, leading some to conclude that ageing is an assault of human being, thereby exciting anguish. The critique here parallels that of others throughout this issue. But Ridenour offers us a distinctive vision of life, including older life, which involves ageing toward death. She articulates a theological ethics of ageing in conversation with Aronson and Augustine, which values persons throughout life's stages. The virtue of being a person is discussed in terms of participation in the divine life with God and others opposing the instrumental and calculable treatments of human being. Opposing such anthropologies, Ridenour's theologically-informed vision of the vocation of being human does not exclude or diminish or dismiss those whose frailties are realised in later life. Instead, it is one in which hope is grounded by a unity of belonging and the promise of patience cultivated by Sabbath rest. In such a vision, those in 
later life, with their illuminating take on time and position relative to eternity, stand as witnesses to our final Sabbath.

Expressions of gratitude must be given to those persons who have participated in the 2020 McDonald Centre Annual Conference, with particular thanks to those authors who have contributed to this issue. Thanks also to Prof Nigel Biggar and Ms Virginia Dunn at the McDonald Centre for Theology, Ethics and Public Life for the support and assistance in facilitating the conference on 'Ageing and Despair'. We are also grateful to Prof Sarah Harper and Dr George Leeson for their collaborations with the McDonald Centre to host a 2020 seminar series on 'The Construction of Ageing', to support the development of the conference, and to welcome the development and publication of the present special issue. Ms Nana Nanitashvili has been instrumental in assisting us throughout the development of this special issue-for her diligent and helpful efforts, we are thankful. The $2020 \mathrm{McD}$ onald Centre Annual Conference was funded, in part, through an endowment furnished by the McDonald Agape Foundation, to whom we express our ongoing gratitude. We also acknowledge, with appreciation, funding from the Wellcome Trust ISSF (204,826/Z/16/Z), which was used to facilitate the conference from which the papers included in this issue have emerged.

\section{References}

Cassim, B. (2015). Successful Aging: Is There an African Perspective? The Gerontologist, 55(Suppl. 2), 754. https://doi.org/10.1093/geront/gnv389.03

Feng, Q., Son, J., \& Zeng, Y. (2015). Prevalence and correlates of successful ageing: A comparative study between China and South Korea. Eur J Ageing, 12, 83-94. https://doi.org/10.1007/ s10433-014-0329-5

Fernández-Ballesteros, R., Garcia, L. F., Abarca, D., Blanc, E., Efklides, A., Moraitou, D., ... Patricia, S. (2010). The concept of 'ageing well' in ten Latin American and European countries. Ageing and Society, 30(1), 41-56. https://doi.org/10.1017/S0144686X09008587

Gilleard, C. (2007). Old age in ancient Greece: narratives of desire, narratives of disgust. Journal of Aging Studies, 21(2), 81-92. https://doi.org/10.1016/j.jaging.2006.02.002

Laslett, P. (1991). A fresh map of life: The emergence of the third age. Harvard University Press.

Møller, V., \& Ferreira, M. (1992). Successful ageing in South Africa: opportunity structures and subjective wellbeing. South African Journal of Gerontology, 1(1), 5-8. https://doi.org/10.21504/sajg.v1i1.10

Neugarten, B. L. (1974). Age groups in American society and the rise of the young-old. The ANNALS of the American academy of political and social Science, 415(1), 187-198. https://doi.org/10.1177/ 000271627441500114

Rabe, M. (2015). Successful ageing amongst elderly women living independently in central areas Of Pretoria. South Africa. African Sociological Review, 19(2), 149-166.

Rowe, J. W., \& Kahn, R. L. (1998). Successful aging. New York: Pantheon.

Publisher's Note Springer Nature remains neutral with regard to jurisdictional claims in published maps and institutional affiliations. 